\title{
OCURRENCE OF Phomopsis helianthi IN ARGENTINA
} AND URUGUAY

\author{
Huguet, N.I.
}

Service Pathology Vegetable, Venado Tuerto. Argentina.

Received: September 10, 2005

Accepted: March 25, 2006

SUMMARY

Phomopsis has been described in Yugoslavia (Muntañola-Cvetković et al., 1980 ) as a fungus responsible of the reduction of sunflower yields. However, during the last two decades in Argentina, Phomopsis was not considered as a limiting pathogen of sunflowers fields.

At the XI International Sunflower Conference held in Mar del Plata, Argentina, in 1985, a paper of Mihaljčević was presented on the pathogenesis of Phomopsis isolates from wild sunflower. In 1992, National University of Entre Ríos (UNER) carried on a special project on the disease.

This report discusses the occurrence of two natural infections recorded during three seasons (2003-2005) in two neighboring locations, one in the central-eastern Argentina (Gualeguay) and another in Uruguay (Mercedes), which are separated by the Uruguay River.

The aims of this study were:

a. To determine and register the spreading of Phomopsis in field conditions.

b. To observe the distribution of the disease.

c. To determine whether hybrids posses genetic tolerance to this pathogen.

d. To make a contribution to sunflower disease map in South America.

As a result of observations under field conditions, we can say that in Uruguay severe attacks of Phomopsis are decisive for sunflower yield reduction. The behavior of commercial hybrids was: tolerant $-27 \%$, intermediate $-30 \%$, susceptible $-43 \%$. The distribution of Phomopsis is increased.

In Argentina, the presence of Phomopsis is low or null.

Key words: sunflower, Phomopsis, Helianthus species, diseases

\section{INTRODUCTION}

Phomopsis has been reported in Yugoslavia (Muntañola-Cvetković et al., 1980) as one a fungus responsible of the reduction of sunflower yields.

* Corresponding author, Phone-Fax (54) 3415308110 ,

e-mail: normet@arnet.com.ar, nhuguet@normahuguet.com.ar 
At the XI International Sunflower Conference, held in Mar del Plata, Argentina, in 1985, Mihaljčević presented a paper on the pathogenesis of Phomopsis isolates from wild sunflower.

During the last two decades in Argentina, Phomopsis was not considered as a limiting pathogen of sunflower fields.

In 1992, National University of Entre Ríos (UNER) carried out a special project.

The aims of this study were:

- To determine and register the spreading of Phomopsis in field conditions.

- To determine whether hybrids possess genetic tolerance to this pathogen.

- To make a contribution to sunflower disease mapping in South America.

\section{MATERIALS AND METHODS}

Occurrence of natural infection of Phomopsis was recorded during the seasons 2003-2005 in two neighboring locations, one in central-eastern Argentina, Gualeguay, and another in Uruguay, Mercedes.

Trials of sunflower hybrids from ASAGIR (Argentine Sunflower Association) and seeds companies are regularly inspected by phytopathologists from the beginning of the flowering stage (R5) till after physiological maturity (R9) (Schneiter and Miller, 1981) for reaction to Phomopsis.

Disease severity was rated by Maširević scale (1999). 1. Healthy steam, 2. Stem with spots, 3. Stem with spots, spots covering stem diameter, 4. Stem enveloped with dark brown spots, 5. Broken stem.

\section{RESULTS}

In the 2003 and 2004 growing seasons in Argentina, ASAGIR inspection of diseases detected Phomopsis symptoms in Gualeguay area.

In the same seasons, INIA reported attacks in Uruguay and a map was prepared of risk of the disease.

During the 2004/05 season in Argentina, the presence of Phomopsis was null in the sunflower trial network.

In Uruguay, repeated attacks have occurred causing severe damage.

The photographs in Figures 1 and 2 show the external and internal canker and canker relationship with crop residues.

In Uruguay, the reaction of commercial hybrids was: tolerant - $27 \%$, intermediate $-30 \%$, susceptible $-43 \%$.

In Uruguay (Mercedes), severe attacks of Phomopsis were decisive for sunflower yield decreases.

The distribution of Phomopsis is increased in Uruguay.

In Argentina, the presence of Phomopsis is low or null. 


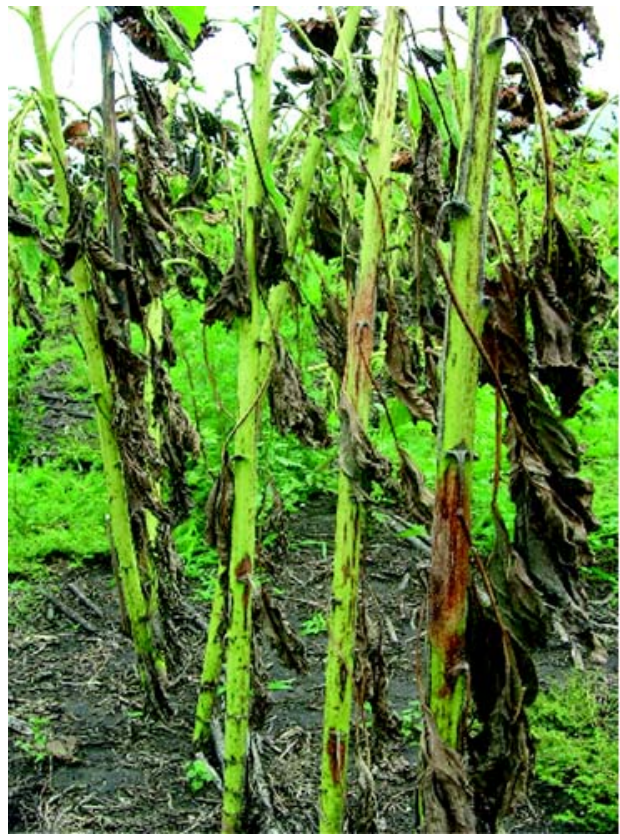

Figure 1: A frequent symptom, external stem canker evolving

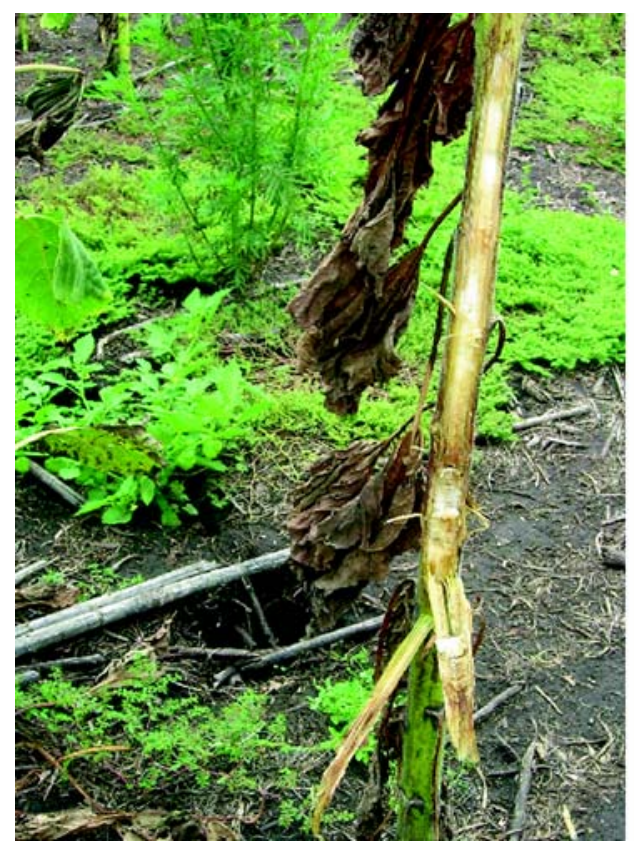

Figure 3: Longitudinal section of the stem showing Phomopsis affects

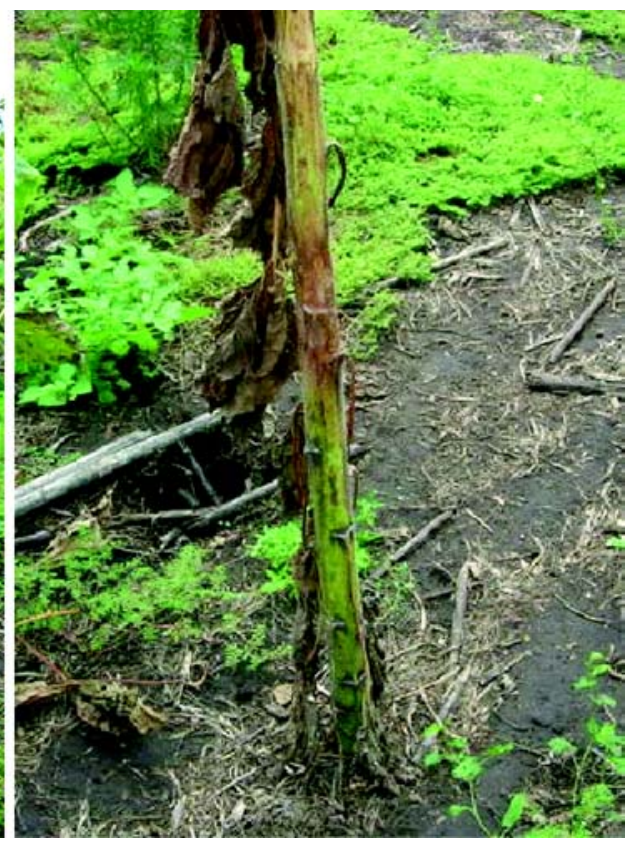

Figure 2: The stem and the plant are completely wilted

\section{Phomopsis-Hybrids Behavior (Uy)}

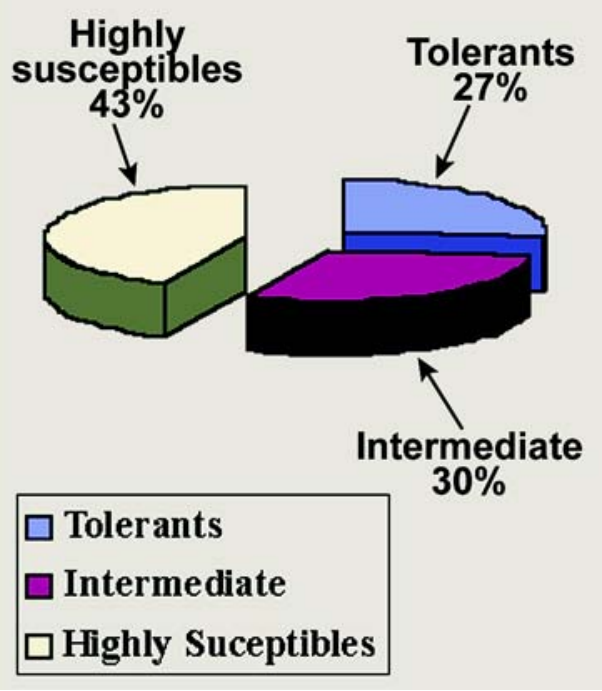

Figure 4: Behavior of commercial hybrids according to Maširević scale 


\section{REFERENCES}

Acimovic, M, 1988 Sunflower disease mapping in Europe and some countries outside Europe for period 1984-1986. HELIA, 11:41-49.

Maširević, S., 1999 Studies on common methodologies and population dynamics of pathogens. Paper FAO Meeting, Dobrich, Bulgaria, 27-30 July 1999

Mihaljčević, M., 1985 Responses of sunflower plants to different Phomopsis isolates. I. From sunflower. XI International Sunflower Conference, Mar del Plata, Argentina, 10-13 March 1985

Munta ola-Cvetković, M., Mihaljčević, M., Petrov, M., 1980 On the Identity of the Causative Agent of a Serious Phomopsis-Diaporthe Disease in Sunflower Plants. Nova Hedwigia, 34: 417435

Schneiter, A.A. and Miller, J., 1981 Description of Sunflower Growth Stages. Crop Sci, 21: 901903

\section{PRESENCIA DE Phomopsis helianthi eN ARGENTINA Y URUGUAY}

\section{RESUMEN}

Phomopsis fue identificado en Yugoslavia (Marić, Maširević, and Mihaljčević, 1980) como uno de los patogenos responsables de la reduccion de rendimientos en girasol.

En Sur America, en 1985 Mihaljčević, M., Muntañola-Cvetković, M. en la XI Internacional Sunflower Conference, Mar del Plata informan sobre la patogenicidad de aislamientos de Phomopsis y estudios de inoculacion con el patogeno aislado a partir de silvestres.

En 1992 la Facultad de Ciencias Agrarias de UNER desarrollo un proyecto especifico sobre Phomopsis.

En la Republica Argentina durante las ultimas dos decadas Phomopsis, no fue considerado uno de los patogenos limitantes de los rendimientos del cultivo girasol.

El presente informe reporta la presencia de dos infecciones naturales registradas durante 2003/04/05 en dos localidades vecinas: una ubicada en el centro-este de Argentina (Gualeguay) y en una localidad del Uruguay (Mercedes) ambas estan separadas por el Rio Uruguay.

Los objetivos de este informe fueron:

Registrar el ataque de Phomopsis en condiciones de campo.

Observar la difusión de la enfermedad .

Determinar tolerancia genetica de hibridos, para este patogeno. Sur.

Realizar un aporte al mapa de enfermedades de girasol en America del

Como resultado de estas observaciones, establecemos diferencias en cuanto a nivel de infeccion natural de Phomopsis, comprobamos que en Argentina la presencia de Phomopsis es baja a nula , mientras que en Uruguay el severo ataque Phomopsis fue responsable de la disminución de rendimiento en la campaña 2004/05. El comportamiento de los hibridos comerciales fue diferente $27 \%$ son tolerantes $30 \%$ intermedio y $43 \%$ fue susceptible al patogeno. 


\section{PRESENCE DE Phomopsis helianthi EN ARGENTINE -} URUGUAY.

\section{RÉSUMÉ}

Phomopsis a été identifié en Yougoslavie en 1980 Marić and Maširević, and Miahaljčević il est un des pathogène responsable de la baisse des rendements en tournesol.

En 1985, a Mar del Plata. XI Internacional Sunflower Conference Sud America, Argentina, Miahaljčević, M Muntañola-Cvetković, ont présenté un rapport sur 1

Identification de Phomopsis en tournesol sylvestre.

En1992 la Facultad de Ciencias Agrarias de UNER a développé un Project pour l'étude du Phomopsis.

Pendan bingo ans, en Argentina, Phomopsis n'a pas été consideré important maladie que íl n'etait pas enregistré 'a la campagne.

Le rapport montre l'apparition de la maladie en cultures aux cotes du fleuve Uruguay, aux années 2003/04/05, ilets apparu a Gualeguay , Argentine et a Mercedes , Uruguay.

Les objectifs rapports sont,

Enregistrer la maladie sur les plantes a la campagne. Observation de la diffusion de la maladie. Déterminer la résistance des hybrides contre Phomopsis. Contribuer à compléter la carte de maladies du tournesol de l'American du Sud.

Finalement on peut dire qu'en Argentine la présence de Phomopsis est basse, presque nulle.

A' Uruguay la maladie est plus important. Les résultats des hybrides commerciales out été le suivants, le $43 \%$ a été susceptible au pathogène, le $30 \%$ a en rendement moyen et le $27 \%$ a été a tolérant au pathogène. 
